\title{
Functioning of the Lubomirskia baicalensis symbiotic community under the conditions of a model experiment
}

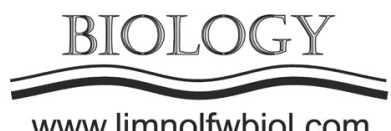

www.limnolfwbiol.com

\author{
Glyzina O.Yu. ${ }^{1 *}$, Konstantinova E.A. ${ }^{2}$, Glyzin L.A. ${ }^{1}$, Fedorova G.A. ${ }^{1,3}$, \\ Avezova T.N. ${ }^{1}$, Belikova A.S. ${ }^{1}$, Itskovich V.B. ${ }^{1}$ \\ ${ }^{1}$ Limnological Institute, Siberian Branch of the Russian Academy of Sciences, Ulan-Batorskaya Str., 3, Irkutsk, 664033, Russia \\ ${ }^{2}$ Irkutsk State University, K. Marx Str., 1, Irkutsk, 664003, Russia \\ ${ }^{3}$ Russian State University of Justice, 23-A, Ivana Franko, Irkutsk, 664033, Russia
}

\begin{abstract}
Experiments on keeping Lubomirskia baicalenis in temperature-controlled aquarium installations have indicated that after three months of incubation of the sponge with the temperature rise from $+4^{\circ} \mathrm{C}$ to $+12^{\circ} \mathrm{C}$ quantitative biochemical parameters of cells in both the sponge itself and its symbionts change. The results of the experiment have revealed that when the water temperature rises above the ecological optimum for the endemic species of the Baikal sponge, Lubomirskia baicalenis, the quantitative composition of demospongic acids will change. The cells of the sponge itself synthesize directly these acids, and they are taxonomic and trophic markers.
\end{abstract}

Keywords: Lake Baikal hydrobionts, Baikal sponges, lipids, fatty acids

A symbiosis of microorganisms with sponges is not only one of the World's most ancient but also one of the most difficult, combining more than 100 species of organisms from various taxonomic groups into a single symbiotic community. Symbionts play an important role in the biotransformation of organic matter. Therefore, studies of adaptive features in an animal organism for the representatives of taxa at a low phylogenetic level are currently very relevant in terms of the ever-increasing anthropogenic pressure on stable ecosystems.

The anthropogenic impact has also changed the functioning of many ecosystems in Lake Baikal. In recent years, there has been a massive death of the community of endemic Baikal sponges (Timoshkin et al., 2019).

The cause of this phenomenon can be determined through a study of a sponge community under laboratory conditions. Previous studies allowed for analysis of the variability of the lipid, pigment and protein composition of the cells of the Baikal sponges (Latyshev et al., 1992; Glyzina and Glyzin, 2014; Itskovich et al., 2017; 2019; Glyzina et al., 2017). Thus, we identified taxonomic differences in the composition of fatty acids in the Baikal sponges and their symbionts and studied the influence of some factors (habitat and light intensity) on chlorophyll-porphyrins, lipids and fatty acids of sponges. We revealed that despite the variability of the fatty acid composition, the features typical of the Baikal sponges are preserved.
During this study, a symbiotic community based on the Baikal endemic sponge Lubomirskia baicalenis (Pallas) (Efremova, 2004) served as a study object, including microalgae, bacteria and unicellular organisms living in sponge cells (Itskovich et al., 2019). The sponge was collected from a depth of $10 \mathrm{~m}$ in the southern part of Lake Baikal and adapted to artificial habitat in aquarium installations at a temperature of $+4^{\circ} \mathrm{C}$ under conditions of flowing Baikal water and a 12-hour light regime.

Analysis of biochemical parameters was carried out using the known methods: the pigment composition was analysed using a MALDI-TOF/TOF Mass Spectrometer (UltrafleXtreme, Bruker Daltonics $\mathrm{GmbH}$, Germany) and MTP AnchorChip 400/384 T F MALDI target (S / N 20823) as well as by high-performance liquid chromatography (HPLC) on a Milikhrom A-02 chromatograph (EkoNova, Novosibirsk); gas chromatography-mass spectrometric analysis of methyl esters in fatty acids was carried out on an Agilent 5973N-GC6890 instrument.

Experiments on keeping Lubomirskia baicalenis in temperature-controlled aquarium installations have indicated that after three months of incubation of the sponge with the temperature rise from $+4^{\circ} \mathrm{C}$ to $+12^{\circ} \mathrm{C}$ quantitative biochemical parameters of cells in both the sponge itself and its symbionts change. The results of the experiment revealed that when the water temperature rises above the ecological optimum for the endemic species of the Baikal sponge, Lubomirskia baicalenis,

*Corresponding author.

E-mail address: glyzina@lin.irk.ru (O.Yu. Glyzina) 
the quantitative composition of demospongic acids will change. The cells of the sponge itself synthesize directly these acids, and they are taxonomic and trophic markers.

The present work was supported by the State Task No. 0345-2016-0002 (AAAA-A16-116122110066-1) "Molecular ecology and evolution of living systems in Central Asia under global environmental changes"; by RFBR and DST according to the research project № 19-54-45034 and RFBR № 20-04-00868; using unique facilities of "Experimental freshwater aquarium complex of Baikal hydrobionts" (LIN SB RAS).

\section{References}

Efremova S.M. 2004. New genus and new species of sponges from the family Lubomirskiidae Rezvoj, 1936. In: Timoshkin O.A. (Ed.), Index of animal species inhabiting Lake Baikal and its catchment area. Novosibirsk, pp. 1261-1278.

Glyzina O.Yu., Bazarsadueva S.V., Glyzin A.V. et al. 2017. Changes in the lipid composition of freshwater sponges upon rise in habitat temperature. Russian Journal of Ecology 2: 152-155. DOI: 10.1134/S1067413616020077
Glyzina O.Yu., Glyzin A.V. 2014. Biochemical response of the oldest symbiotic multicellular oz. Baikal on the change in the temperature regime of their habitat. Voda: Khimiya i Ekologiya [Water: Chemistry and Ecology] 1: 71-79. (in Russian)

Itskovich V., Glyzina O., Kaluzhnaya Ox. 2017. Intraspecific and interspecific sequence variability in the ITS region of the rDNA of freshwater sponges of Lake Baikal and East Siberia. Inland Waters 7(3): 267-271. DOI: 10.1080/20442041.2017.1320507

Itskovich V.B., Shigarova A.M., Glyzina O.Y. et al. 2019. Sponges Lubomirskiidae as bioindicators of the state of Lake Baikal. Limnology and Freshwater Biology 1: 172-176. DOI: 10.31951/2658-3518-2019-A-1-172

Latyshev N.A., Zhukova N.V., Efremova S.M. et al. 1992. Effect of habitat on participation of symbionts in formation of the fatty acid pool of fresh-water sponges of Lake Baikal. Comparative Biochemistry and Physiology 102B: 961-965. DOI: 10.1016/0305-0491(92)90109-5

Timoshkin O.A., Bondarenko N.A., Kulikova N.N. et al. 2019. Protection of Lake Baikal requires more stringent, not more lenient, environmental regulation. Journal of Great Lakes Research 45(3): 401-402. DOI: 10.1016/j. jglr.2019.04.002 